\title{
Rekayasa Informasi Untuk Mendukung Keberlangsungan Proses Service Level Management
}

\author{
Bayu Rima Aditya*, Muhammad Barja Sanjaya \\ Fakultas Ilmu Terapan, Universitas Telkom, Indonesia \\ Email: 1,"bayu@tass.telkomuniversity.ac.id, ${ }^{2}$ mbarja@ tass.telkomuniversity.ac.id \\ Email Penulis Korespondensi: bayu@tass.telkomuniversity.ac.id
}

Submitted 03-02-2020; Accepted 27-02-2020; Published 26-04-2020

\begin{abstract}
Abstrak
Komponen kunci dari keseluruhan strategi Service Level Management (SLM) penyedia layanan adalah dibuatkannya Service Level Agreement (SLA). Penyedia layanan harus selalu memastikan bahwa SLA untuk pelanggan dapat terpenuhi. Hal yang menyebabkan kegagalan dalam pemenuhan SLA adalah ekpektasi bisnis yang terlalu tinggi pada saat membuat SLA, sehingga terlihat bahwa terdapat perbedaan pandangan antara perspektif bisnis dan perspektif TI. Tujuan pada penelitian ini adalah pembentukan kerangka kerja untuk membantu tercapainya keseimbangan antara kualitas yang diinginkan penerima layanan dengan yang disediakan oleh penyedia layanan. Metodologi yang digunakan dalam penelitian adalah dengan menggunakan pendekatan rekayasa informasi yang terdiri dari perencanaan analisis keterkaitan visi, perencanaan dampak teknologi, analisis critical factor success (CFS), analisis masalah dan tujuan, serta pengidentifikasian area bisnis. Penelitian ini telah dapat memberikan gambaran secara jelas bahwa pelaksanaan SLM memerlukan suatu sistem informasi yang terpadu untuk melengkapi kepentingan antar fungsi di dalam perusahaan.
\end{abstract}

Kata Kunci: Rekayasa Informasi, Service Level Management, Service Level Agreement, Sistem Informasi

Abstract

The main component of the entire strategy in Service Level Management (SLM) as a service provider is shown by implementing the Service Level Agreement (SLA). The service provider has to always guarantee that SLA which is indeed determined for a customer is achieved and fulfilled. The thing causing a failure in fulfilment of SLA is the expectation of business that is categorized in high indication while SLA establishment is still in progress, so it is indicated that there is a difference of perception between business and IT paradigm. The aim of this study is to build a framework to facilitate the achievement of a balance between the expected quality for the customer as the receiver party and the service which is offered by a service provider. The methodology which is applied in this study is by using an approach of information engineering that consists of planning the analysis of related vision, planning of the technology effect, analysis of critical success factor, analysis of problem and purpose, as well as the identification of business area. The research which is conducted has given an obvious perspective paradigm in general that an integrated information system is indeed needed into the implementation of SLM to complete the significance among the functional divisions in a company.

Keywords: Information Engineering, Service Level Management, Service Level Agreement, Information System

\section{PENDAHULUAN}

Salah satu strategi menjaga kepuasan pelanggan adalah dengan dibuatkannya Service Level Agreement (SLA) yang merupakan kesepakatan antara penyedia jasa dan pengguna jasa mengenai tingkat (mutu) layanan serta merupakan komponen kunci dari keseluruhan strategi Service Level Management (SLM). Hal yang paling penting untuk diperhatikan oleh penyedia layanan adalah memastikan bahwa SLA untuk pelanggan harus dapat dipenuhi [1]. Hal ini disebabkan karena kegagalan pemenuhan SLA akan berdampak serius terhadap perusahaan, terutama pengaruhnya terhadap kerugian finansial perusahaan [2][3].

Menurut hasil penelitian yang dilakukan tim riset Compuware, didapat bahwa $41 \%$ dari 321 departemen IT di dunia mengaku memiliki pengetahuan yang sangat terbatas mengenai SLA. Dan hasil risetnya pun memberikan informasi bahwa rata-rata perusahaan IT di dunia gagal memenuhi SLA, mereka hanya dapat memenuhi $26 \%$ dari yang ditargetkan [4]. Hal yang menyebabkan kegagalan dalam pemenuhan SLA adalah ekpektasi bisnis yang terlalu tinggi pada saat membuat SLA, sehingga terlihat bahwa terdapat perbedaan pandangan antara perspektif bisnis dan perspektif TI [5].

Informasi-informasi yang tercantum di dalam SLA bukanlah hanya sekedar janji-janji melainkan informasi yang memang berkualitas [6]. Menariknya, dalam dekade terakhir telah terjadi perubahan persepsi pelanggan terkait kriteria kualitas dari informasi [7]. Proses yang bertanggung jawab untuk menegosiasikan SLA dan memastikan bahwa perjanjian tersebut dipenuhi adalah proses SLM. Dengan kata lain SLM menjadi jembatan komunikasi antara perusahaan dengan pelanggan dan unit bisnis perusahaan. Beberapa masalah yang sering muncul ketika implementasi proses SLM diantaranya adalah seperti omplementasi SLM tidak merata, implementasi belum memenuhi standar kelengkapan proses, struktur dokumentasi SLA berbeda-beda di tiap unit, unit-unit yang ada diperusahaan tidak mempunyai kesatuan pemahaman tentang SLM dan SLA, serta kurangnya konsistensi, koordinasi serta monitoring pelaksanaan SLM.

Dari permasalahan-permasalahan yang telah disebutkan, maka pelaksanaan SLM memerlukan suatu sistem informasi yang terpadu antar setiap fungsi dalam perusahaan. Untuk itu dilakukan suatu pengembangan informasi strategis yang menggunakan beberapa metodologi yang ada dalam kerekayasaan informasi, khususnya analisis area bisnis. Tujuan yang ingin dicapai pada penelitian ini bukan untuk merancang suatu sistem, tetapi sebagai pembentukan kerangka kerja yang akan memberikan gambaran secara jelas bahwa sistem dirancang untuk melengkapi kepentingan bersama antar fungsi. Dengan harapan dapat membantu tercapainya keseimbangan antara kualitas yang diinginkan penerima layanan dengan yang disediakan oleh penyedia layanan 


\section{METODE PENELITIAN}

Metode penelitian yang digunakan dalam penelitian ini dalam rangka pengembangan informasi strategis dengan pendekatan kerekayasaan informasi dapat dilihat pada Gambar 1.

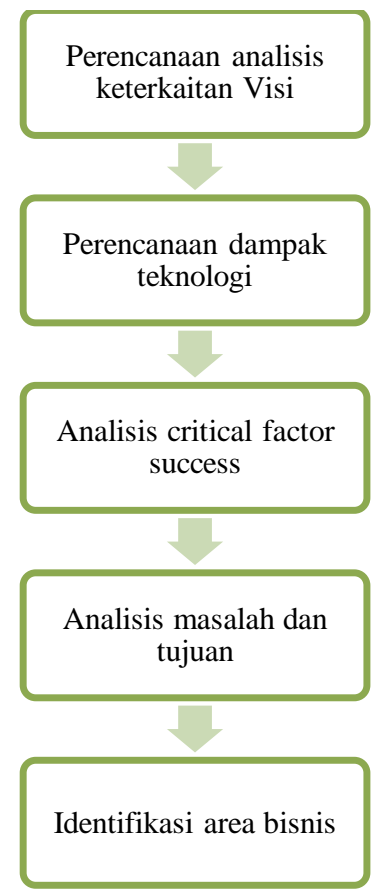

Gambar 1. Pendekatan metode rekayasa informasi

Secara rinci dijelaskan sebagai berikut.

a. Perencanaan analisis keterkaitan visi.

Tahapan ini bertujuan untuk memberikan gambaran mengenai teknologi yang digunakan oleh perusahaan untuk dapat berhubungan dengan pihak terkait, dengan harapan dapat memberikan keuntungan bagi bisnis perusahaan. Penggunaan peralatan teknologi elektronis seperti perangkat keras, lunak, serta jaringan komputer akan memberikan kemudahan bagi pimpinan perusahaan dalam memformulasikan visi strategis perusahaan.

b. Perencanaan dampak teknologi.

Tahapan ini bertujuan untuk memberikan gambaran dampak penggunaan teknologi bagi perusahaan dalam sistem informasi berbasis komputer. Setiap perubahan teknologi sangat berhubungan dengan unit usaha perusahaan, tujuan dan masalah, serta dapat menciptakan peluang bisnis dan perubahan dalam penggunaan sumber-sumber yang ada di perusahaan. Selain itu, tahap ini juga memberikan gambaran akan ancaman dari perubahan teknologi. Perubahan teknologi dapat berupa perubahan komputer, telekomunikasi, teknologi penyimpanan data, basis data, perangkat lunak, dan peralatan lainnya. Sehingga dalam menghadapi perubahan teknologi, diperlukan usaha persiapan berdasarkan skala waktu yang ditetapkan.

c. Analisis Critical Factor Success (CFS).

Analisis CFS dapat mempengaruhi tingkat kegiatan strategis, terutama dalam menitikberatkan kegiatan perusahaan supaya lebih efektif, serta memberikan informasi yang sifatnya kritis. Sehubungan dengan pengembangan CFS, informasi kritis harus disiapkan dalam rangka melakukan penyelidikan terhadap faktor kekritisannya. Atas dasar tujuan dan faktor sukses kritis, perusahaan dapat memberikan asumsi secara pasti, dimana validitas asumsi ini terkadang berubah disesuaikan dengan waktu.

d. Analisis masalah dan tujuan.

Setiap perusahaan mempunyai sasaran yang pasti. Sasaran yang akan dicapai adalah dengan menggabungkan sasaran individu serta sasaran setiap tingkatan manajemen di perusahaan. Sasaran perusahaan harus selalu dilakukan penilaian kembali secara berkala untuk dievaluasi kembali pada tahap berikutnya.

e. Identifikasi area bisnis.

Tahap ini bertujuan untuk menggambarkan kebutuhan informasi berdasarkan area bisnis di perusahaan. Identifikasi area bisnis dilakukan dengan membuat suatu model mengenai pengembangan informasi strategis menggunakan bagan atau matriks yang menggambarkan hubungan fungsi kegiatan dan subyek data.

\subsection{Service Level Management}

Layanan adalah suatu nilai (value) yang diberikan kepada pihak lain (penerima layanan) yang bukan berbentuk barang (benda fisik dengan nilai material) [8]. Sedangkan SLM adalah proses yang bertanggung-jawab untuk menegosiasikan SLA, dan 
memastikan bahwa perjanjian tersebut terpenuhi. Konsep SLM menurut IT Infrastucture Library (ITIL) adalah suatu pemberian target layanan yang disepakati kepada bisnis dan informasi yang diperlukan manajemen untuk memastikan targettarget tersebut tercapai [9]. Konsep lain juga ditemukan berdasarkan ISO 20000 ITSM yang menyatakan bahwa SLM adalah suatu proses penyampaian layanan dengan pendekatan untuk membangun dan mencapai sasaran level layanan yang efektif dan menciptakan SLA yang bermanfaat [10]. Sehingga dari konsep tersebut maka dapat dikatakan bahwa SLM menjadi jembatan komunikasi antara perusahaan dengan pelanggan dan unit bisnis perusahaan. Adapun tujuan dari SLM adalah memastikan bahwa layanan yang disediakan untuk pengguna layanan pada level kualitas dan harga yang disepakati, serta meyakinkan bahwa layanan pada level yang disepakati terjaga, terawasi dan dikembangkan secara berlanjut [9][10].

Kebijakan tingkat layanan dalam SLM mengarahkan standar layanan kepada tujuan bisnis setiap penyedia layanan, sehingga akan berbeda untuk setiap perusahaan. Dengan demikain SLM dapat memastikan kebutuhan tingkat performansi yang baru digunakan, atau penambahan dan modifikasi layanan yang dikembangkan sesuai dengan kebutuhan bisnis dan harapan penerima layanan. Kesuksesan proses SLM tergantung pada efektivitas interaksi organisasi dengan layanan dan penyedia layanan dalam mendefinisikan kebutuhan bisnis dan tingkat layanan. Karakter organisasi SLM untuk setiap perusahaan juga berbeda satu sama lainnya, bergantung pada kebutuhan dan ukuran perusahaan itu sendiri.

\subsection{Rekayasa Informasi}

Rekayasa Informasi diartikan sebagai kumpulan prosedur yang saling berkaitan, dalam membangun system informasi berbasis computer suatu perusahaan. Fokus dari rekayasa informasi adalah penyimpanan data, pengelolaan data, dan pembentukan laporan berdasarkan data tersebut oleh komputer. Rekayasa informasi ini jika diterapkan akan membentuk aplikasi-aplikasi terstruktur di perusahaan [11]. Adapun tujuan utama dari rekayasa informasi adalah untuk mendukung kebutuhan pimpinan perusahaan, mengolah data untuk mencapai tujuan usaha, meningkatkan nilai tambah sistem komputer dan pengembangan aplikasi, menyediakan informasi secara cepat bila dibutuhkan, serta menciptakan koordinasi dalam penggunaan data di setiap unit atau fungsi kegiatan di perusahaan. Bentuk analisis area bisnis yang tersedia adalah sebagai berikut [11].

a. Exception Analysis.

Pengintegrasian data dalam proses perencanaan dapat diambil berdasarkan prosedur yang benar serta menyusunnya dalam daftar setiap kejadian tanpa memperhatikan kriteria. Pengecekan pemasukan data dapat langsung ditujukan kepada pemakai sesuai dengan kebutuhannya.

b. Level Consistency Analysis.

Melakukan verifikasi hubungan antara dua tingkatan di dalam manajemen perusahaan. Seperti dukungan tingkat strategis dalam rangka pengembangan informasi strategis untuk membantu pembentukan subyek basis data yang dapat digunakan bersama dalam aplikasi perusahaan.

c. Affinity Analysis.

Suatu analisis pengukuran kebersamaan dapat ditentukan berdasarkan subyek data-subyek data, kemudian dari subyek data tersebut dikelompokkan kedalam kelompok dalam rangka pencapaian efisiensi aplikasi.

d. Project Action Analysis.

Melakukan analisis pendefinisian suatu proyek yang terbentuk dari hasil pengelompokan data affinity analysis dalam bentuk entitas serta cara pengolahaanya. Data dapat digabungkan melalui pengolahan yang benar, dan proyek dapat dihubungkan untuk mencapai tujuan yang pasti. Penggabungan ini dapat dilakukan dengan menghubungkan kegiatan dan subyek data-subyek data ke dalam suatu matriks.

e. Project Ranking Analysis.

Pengolahan perencanaan akan melakukan analisis estimasi proyek yang dapat dikontribusikan dalam pencapaian tujuan

\section{HASIL DAN PEMBAHASAN}

\subsection{Pendekatan SLM berdasarkan Perencanaan Analisis Keterkaitan Visi}

Pembentukan sistem informasi berbasis jaringan komputer dengan bantuan penggunaan teknologi merupakan kebutuhan utama bagi perusahaan, terutama dalam melakukan hubungan dengan pihak-pihak terkait, seperti terlihat pada Gambar 2.



Gambar 2. Keterkaitan Visi Pada Proses SLM 


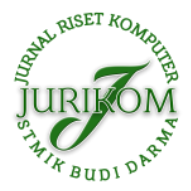

JURIKOM (Jurnal Riset Komputer), Vol. 7 No. 2, April 2020 e-ISSN 2715-7393 (Media Online), p-ISSN 2407-389X (Media Cetak) DOI 10.30865/jurikom.v7i2.2012 Hal 194-199

Pengembangan informasi strategis perusahaan yang erat kaitannya dengan pendekatan rekayasa informasi, merupakan suatu kegiatan yang harus dilaksanakan untuk dapat merubah sistem informasi perusahaan. Pelaksanaan pengembngan informasi strategis tersebut dapat dilakukan di perusahaan dengan melihat bagaimana pendekatan perusahaan terhadap penggunaan beberapa metodologi rekayasa informasi.

\subsection{Pendekatan SLM berdasarkan Analisis Dampak Teknologi}

Perkembangan teknologi akan membawa dampak bagi perusahaan, terutama dalam membantu kemudahan aliran informasi dari setiap fungsi yang terkait dengan SLM. Hal ini tentunya akan memberikan keuntungan bagi perusahaan dalam melaksanakan proses SLM yang pada akhirnya dapat mendukung tercapainya pemenuhan SLA guna mempertahakankan kepuasan pelanggan. Di samping memberikan peluang bisnis, dampak kemajuan teknologi dapat juga menjadi ancaman bagi perusahaan. Misalnya hacker atau sejenisnya. Basis data pada proses SLM dapat dilihat pada Gambar 3.

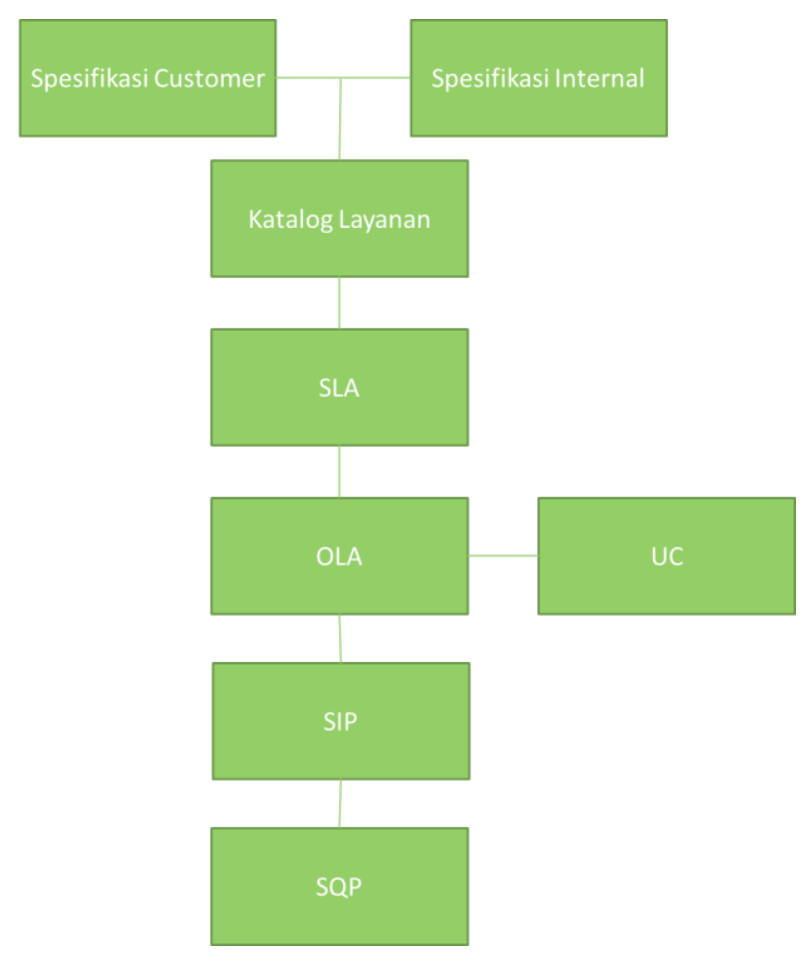

Gambar 3. Basis Data Proses SLM

Divisi Service Level Manager membuat basis data Spesifikasi Customer. Divisi Service Manager membuat basis data Spesifikasi Internal. Basis Data Spesifikasi Customer dan Basis data Spesifikasi Internal digunakan oleh Divisi Service Catalog Manager untuk membuat basis data Katalog Layanan. Basis data Katalog Layanan digunakan oleh divisi Service Level Manager untuk membuat basis data SLA. Divisi Service Manager kemudian menggunakan basis data SLA untuk membuat OLA, UC, SIP dan SQP.

\subsection{Pendekatan SLM berdasarkan Analisis Critical Factor Success}

Analisis ini dapat membantu pimpinan perusahaan dalam memfokuskan kegiatan masing-masing divisi dan membantu menentukan kebutuhan informasi.Critical Factor Success (CFS) adalah hasil dari pengukuran kinerja para individu, divisi dan perusahaan dalam pencapaian tujuan serta perkembangan bisnis. Bentuk CFS dapat disesuaikan dengan kondisi perusahaan secara keseluruhan. CFS untuk proses SLM yaitu formulasi yang akurat dari misi dan tujuan proses SLM, keahlian bisnis dan teknikal dari peran di dalam SLM, definisi yang jelas dari tugas dan peraturan dalam proses SLM, dan kesardaran tentang proses SLM diantara pekerja dari organisasi pihak penyedia dan penerima layanan.

Adapun Key Performance Index (KPI) dari proses SLM meliput persentase target tingkat layanan penyedia jasa yang tak tercapai, persentase target tingkat layanan penyedia jasa yang terancam masalah atau terancam tak tercapai, persentase persepsi dan kepuasan penerima layanan penyedia jasa berdasarkan capaian level layanan, melalui evaluasi layanan dan tanggapan dari survey kepuasan penerima layanan, persentase masalah level layanan penyedia jasa yang disebabkan kontrak dukungan pihak ketiga, dan persentase masalah tingkat layanan penyedia jasa yang disebabkan Operational Level Agreements (OLA) internal.

\subsection{Pendekatan SLM berdasarkan Analisis Masalah dan Sasaran}

Berdasarkan CSF dan KPI perusahaan, pencapaian sasaran akan selalu dihubungkan dengan masalah-masalah yang muncul. Setiap masalah akan dibuatkan daftarnya berikut pemecahan masalah dalam rangka pencapaian sasaran. Untuk ini diperlukan 
pembobotan ranking terhadap pemecahan masalah yang harus dilakukan perusahaan. Daftar ranking pemecahan masalah berdasarkan bobotnya dapat dilihat pada Tabel 1 .

Tabel 1. Ranking pemecahan masalah

\begin{tabular}{|c|c|c|c|}
\hline Masalah & Solusi & Ranking & Sasaran \\
\hline Implementasi SLM tidak merata & Komunikasi Organisasi & 1 & Implementasi SLM merata \\
\hline $\begin{array}{l}\text { Implementasi belum memenuhi standar } \\
\text { kelengkapan proses }\end{array}$ & Standarisasi & 2 & $\begin{array}{l}\text { Terstandarisasi Kelengkapan } \\
\text { Proses }\end{array}$ \\
\hline Struktur dokumentasi SLA berbeda tiap unit & Standarisasi & 1 & $\begin{array}{l}\text { Terstandarisasi Dokumentasi } \\
\text { SLA }\end{array}$ \\
\hline $\begin{array}{l}\text { Unit-unit yang ada diperusahaan tidak } \\
\text { mempunyai kesatuan pemahaman tentang } \\
\text { SLM dan SLA }\end{array}$ & Knowledge Sharing & 1 & $\begin{array}{l}\text { Kesatuaan pemahaman tentang } \\
\text { SLM dan SLA }\end{array}$ \\
\hline $\begin{array}{l}\text { Kurangnya konsistensi, koordinasi serta } \\
\text { monitoring pelaksanaan SLM }\end{array}$ & Efisiensi Opersional & 2 & $\begin{array}{l}\text { Mengurangi ketidakefisiensian } \\
\text { operasional }\end{array}$ \\
\hline
\end{tabular}

Ranking 1 artinya harus segera dilakukan dengan jalan melakukan koordinasi antar divisi, sedangkan ranking 2 adalah dengan cara lebih memprofesionalkan fungsi-fungsi yang ada di perusahaan.

\subsection{Pendekatan SLM berdasarkan Pengidentifikasian Area Bisnis}

Dari daftar yang dibuat dalam analisis masalah dan sasaran, diperlukan suatu tindakan yang harus dilaksanakan segera di perusahaan, yaitu melakukan koordinasi antar fungsi terutama dalam pembentukan sistem informasi masing-masing divisi. Sistem informasi yang dihasilkan setidap fungsi berdasarkan penggunaan basis data secara bersama merupakan langkah awal analisis area bisnis yang berdasarkan exception analysis dan level consistency analysis.

Basis data tersebut merupakan sekumpulan data kegiatan-kegiatan yang dikelompokkan berdasarkan kebutuhan masing-masing fungsi. Dari basis data tersebut akan dibuatkan matriks mengenai keterhubungan data dengan fungsinya. Data dalam hal ini dikelompokkan sebagai entitas yang dapat digunakan oleh setiap fungsi yang ada di perusahaan. Tabel 2 menunjukkan hubungan setiap fungsi dengan basis data.

Tabel 2. Hubungan fungsi dan basis data

\begin{tabular}{cccccc} 
& \multicolumn{5}{c}{ Fungsi } \\
\cline { 2 - 5 } Basis Data & $\begin{array}{c}\text { Pemilik } \\
\text { Proses }\end{array}$ & $\begin{array}{c}\text { Service } \\
\text { Level } \\
\text { Manager }\end{array}$ & $\begin{array}{c}\text { Business } \\
\text { Relationship } \\
\text { Manager }\end{array}$ & $\begin{array}{c}\text { Service } \\
\text { Manager }\end{array}$ & $\begin{array}{c}\text { Service } \\
\text { Catalogue } \\
\text { Manager }\end{array}$ \\
\hline $\begin{array}{c}\text { Spesifikasi Customer } \\
\text { Spesifikasi Internal }\end{array}$ & $\mathrm{x}$ & $\mathrm{x}$ & $\mathrm{x}$ & \\
Katalog Layanan & $\mathrm{x}$ & $\mathrm{x}$ & $\mathrm{x}$ & $\mathrm{x}$ & \\
SLA & & $\mathrm{x}$ & $\mathrm{x}$ & $\mathrm{x}$ & \\
OLA & $\mathrm{x}$ & & $\mathrm{x}$ & \\
UC & & $\mathrm{x}$ & $\mathrm{x}$ & & \\
SIP & & &
\end{tabular}

\section{KESIMPULAN}

Beberapa kesimpulan dari penelitian ini adalah sebagai berikut.

a. Perusahaan memang membutuhkan informasi strategis yang berkaitan dengan proses SLM. Informasi tersebut merupakan masukan yang sangat penting bagi perusahaan untuk memenuhi SLA.

b. Pendekatan penelitian dengan pendekatan metodologi rekayasa informasi ini telah memberikan hasil temuan berupa pengelompokkan area bisnis berdasarkan basis data dan fungsi kegiatan di perusahaan.

c. Pengelompokkan basis data mencerminkan suatu proses SLM yang cukup ideal.

d. Kondisi sistem informasi perusahaan saat ini belum sampai pada taraf menghasilkan informasi strategis seperti yang diharapkan berdasarkan kebutuhan ideal perusahaan.

Adapun beberapa saran yang berkaitan dengan penelitian ini adalah sebagai berikut.

a. Hasil pengelompokan area bisnis dapat lebih dipertajam dan diperinci lagi dengan melibatkan lebih banyak masukan dan tanggapan dari pihak end-user. Supaya lebih efisien, disarankan untuk membentuk suatu kelompok kerja sementara yang terdiri dari wakil-wakil divisi yang bertugas mendefiniskan area-area bisnis tersebut secara lebih matang dan terintegrasi.

b. Dalam pengembangan sistem informasi strategis diperlukan dukungan penuh dari pihak manajemen puncak, karena dapat dipastikan akan terjadi perubahan yang cukup besar pada konfigurasi sistem, prosedur pengolahan data, dan aplikasi yang berjalan di perusahaan saat ini. 


\section{REFERENCES}

[1] Hanemann, Schmitz, D., \& Sailer, M. (2005). A framework for failure impact analysis and recovery with respect to service level agreements. In the IEEE International Conference on Services Computing, Florida USA.

[2] Knight, S., \& Burn, J. (2005). Developing a framework for assessing information quality on the World Wide Web. Information Science Journal, 8, pp.159-172,.

[3] Rana, O.F., Warnier, M., Quillinan, T. B., Brazier, F., \& Cojocarasu, D. (2008). Managing Violations in Service Level Agreements. In Grid Middleware and Services, Boston, MA: Springer US, pp. 349-358.

[4] www.computerworld.co.nz

[5] Abdelatey, A., Elkawkagy, M., El-Sisi, A., \& Keshk, A. (2017). A Multilateral Agent-Based Service Level Agreement Negotiation Framework. In the International Conference on Advanced Intelligent Systems and Informatics.

[6] Halili, M. K., \& Cico, B. (2018). Towards Custom Tailored SLA in IaaS Environemnt Through Negotiation Model: An Overview. In the Mediterranean conference on embedded computing,.

[7] Jin, L.J., Machiraju, V., \& Sahai, A. (2002). Analysis on Service Level Agreement of Web services. Hewlett-Packard Laboratories.

[8] Krishna, A., Dangayach, G.S., \& Jain, R. (2011). Service recovery: Literature review and research issues. J Serv Sci Res, 3(71).

[9] Maita, I., \& Akmal, S. (2016). Analisis tata kelola teknologi informasi dengan best practice itil v3 service operation (Studi Kasus: Pustaka dan Arsip Kampar). Jurnal Rekayasa dan Manajemen Sistem Informasi, 2(1), pp. 60-65.

[10] Menken, \& Blokdijk, G. ISO/IEC 20000 Foundation Complete Certification Kit. The Art of Service.

[11] Martin, J. (1989). Strategic Information Planning Methodologies, Second Edition, Prentice Hall. 